\title{
"Under The Hand" Divorce
}

\section{Islamic Law Study of the Implementation of Divorce}

\author{
Oom Mukarromah \\ Lecturer of Sultan Maulana Hasanudin Islamic Public Institute, Banten, Indonesia \\ Jl. Jendral Sudirman No. 30 Serang, Banten, Indonesia
}

Tel: 0877-7428-6509Ｅmail: oommukarromah1965@yahoo.com

Entus Syamsurrizal

Officer of Religious Affairs Office in Tirtayasa, Serang, Banten, Indonesia

Jl. Sulthan Agung Tirtayasa No. 45 Tirtayasa, Serang-Banten

Tel: 0878-0957-7380Ｅmail: esyamsurrizal@gmail.com

Received: June 28, 2016 Accepted: August 20, 2016 Published: August 23, 2016

doi: 10.5296/jsss.v4i1.9674 URL: http://dx.doi.org/10.5296/jsss.v4i1.9674

\begin{abstract}
Islamic Law regulates marriage and divorce sufficiently; Islamic jurists argue that if someone sentences the word talak and its kind to his wife then the talak is considered as valid. Meanwhile, positive law states that "Talak is a declaration of a husband performed in front of court session in Religious Court which becomes one of the reasons of divorce". The fact shows that the people of Carenang, Serang, tend to refer on the Islamic law of divorce, not the one declared before the trial court. This matter engenders the illegal aspect of law, such as issuing a false death certificate to the former spouse. In order to elucidate the problem, the author proposes two main questions: (1) How is the concept of "under the hand" divorce based on fiqih and positive law?; (2) How is the Islamic Law review on the Article 39 Point 1 Law No. 1 of 1974 about Marriage and Article 34 of Government Regulations No. 9 of 1975 ? This study is conducted in normative jurisdiction and sociological jurisdiction which is comparatively descriptive analytic. This study is also conducted through mashlahah mursalah approach and Bentham utility principle. The results of the study show that; first, "under the hand" divorce performed by Carenang's people is considered valid through the
\end{abstract}


eye of Islamic Law, while it is invalid based on Positive Law due to the absence of the pledge before the trial court. Second, the behavior of "under the hand" divorce in Carenang has become a social fact and is included in Al-Maslahah al-Daruriyah category. The enactment of divorce law regulated by Article 39 Point 1 Law No. 1 of 1974 about Marriage and Article 34 of Government Regulations No. 9 of 1975 is covered in the Al-Maslahah al-Hajiyah category.

Keywords: Divorce, Under the hand, Islamic law, Marriage law

\section{Introduction}

\subsection{Introduction of the Problem}

The validity of the next household (next marriage) relies on the validity of the previous divorce. A following marriage becomes haram (restricted) for a woman (former wife) when the previous divorce act is invalid, because it means that the woman performs poliandri (has more than one husband in the same time). Meanwhile, for the husband, an invalid divorce is considered as poligami without the permission of the first wife; or if the fourth wife is divorced, it means that the next marriage is considered as the fifth wife. A problem arises because there are two regulations of divorce law developed in the society, fiqih and the existing law.

The Islamic jurists (fuqaha) argue that if someone states the word talak to his wife then the talak is considered as valid. Due to the consideration of having declared a marital break, it is restricted for them to have intercourse before having reconciliation or other law regulations that enable them to return as husband and wife (Note 1).

Meanwhile, in Act No. 1 of 1974 on Marriage (Act No.1/1974) and Government Regulation No. 91975 (GR. No. 9/1975) concerning the implementation of Law No.1/1975 in a general description there is no definition of divorce, except for the definition of divorce that is stated in Article 117 of the Islamic Law Compilation (KHI) written as follows: "Talak (divorce) is a husband pledge before the trial courts that becomes one cause of marital break, as refer to the procedure in Article 129, 130 and 131" (Note 2). Article 129 of KHI is written as follows: "A husband who would drop divorce to his wife has to file a petition either verbally or in writing to the courts that regulate the wife's residence on the grounds and requested that the trial be held for that purpose."

In Article 130 of KHI written as follows: "Religious Court may grant or refuse the application and of the decision may be requested an appeal and cassation". While in Article 131 of KHI written: "The Religious Court is concerned to learn the petition referred to Article 129 no later than thirty days to call the applicant and his wife to ask for an explanation of everything connected with the intention of dropping divorce".

Article 39 paragraph (1) of Law No.1/1974 states that: "Divorce can only be done in front of the Court after the relevant court endeavored and unsuccessfully tried to reconcile the two sides" (Note 3). According to Article 14 of Government Regulation No. 9/1975, it is stated that: "A man who has held a marriage according to Islam, which is going to divorce his wife, filed a letter to the court in the place of residence, which contains a notice that he intends to divorce his wife and the reasons, and asks the Court to hold a session for that purpose" (Note 4).

The article is lex specialist addressed to the husband who will divorce his wife, while Article 
34 of Government Regulation No. 9/1975 is a lex specialist that explains to the wife who sues her husband. The Article is written as follows: Paragraph (1) The decision regarding divorce is pronounced in an open trail. Paragraph (2) A divorce is considered to occur with its aftermaths as from the time it is registered in the registration list at the registration office by the Registrar Employees, except for those who are Islam, starting from the fall of the ruling Religious Courts that already have binding legal force (Note 5).

Based on its definition of fiqh (jurisprudence) and positive law, the divorce has similarities and differences as follows: a)The similarity, understanding of divorce in fiqh, Law No. $1 / 1974$ and in KHI ie talaq pronounced by a husband to his wife; b)The difference, in fiqh the divorce statement is pronounced by the husband at uncertain time and place, whereas in KHI and Law No.1/1974 after divorcing application was granted by the Court and a pronouncement must be made before the trial court.

\subsection{Statements of Problems}

"Under the hand" divorce is the practice of ending a marriage bond through the statement of a husband to wife outside the court. "Under the hand" divorce according fiqh is considered as valid. Meanwhile, positive law confirms that the definition of talak (divorce) itself according to Article 117 of the KHI is the pledge of the husband before the courts that became one cause of marital break. Therefore, the pledge of talaq which is not stated before the Court for Justice Religion was not officially accepted as a divorce.

The difference between this legal decision resulted in divorce behavior within the society, such as in Carenang district. Muslims in this district consider "under the hand" divorce lawfully accepted referring to fiqh. However, it is invalid according to the positive law of divorce due to its placement outside the illegitimate religion court. Latter, when one wants to have a post-divorce marriage, which requires a court decree of divorce from the court; administrative manipulation took place, such as the fake issuance of a certificate as a "widower/left-die widow".

This situation is an empirical legal problems, namely the fact that the law allegedly infringed by reference to different laws, which are equally strong. On the other side, this issue shows the effect of the positioning of positive law which develops other behaviors of the legal aspect violation, such as issuing a death certificate of the former spouse.

\subsection{Previous Studies}

Study of'under the hand" divorce is not an unfamiliar topic in the academic world. Prior to this study, there are many theses and dissertations that explore and examine the status of the "under the hand" divorce and its aftermath. The studies are as follow:

Thesis of Mugi Lestari, Susanti, The Analysis of Islamic Law on "Under the Hand" Divorce (Case Studies in Transmigration Regional Mukti Manungal village, Menthobi Raya District, Lamandau Regency, Central Kalimantan) (Note 6). The research concerns on (1) how is the practice of "under the hand" divorce in Manunggal Mukti Village; (2) how is the status of "under the hand" divorce according to Islamic law and positive law in Indonesia. The study indicates that there are nine people who have conducted under the hand divorce in Manunggal Mukti Village and they also have conducted marriage in accordance with marriage rules under Islamic regulations and recorded in the Office of Religious Affairs 
(KUA) Lamandau District, so they got Marriage Certificates.

Ginting, Fitria Handayani, Divorce in "under the hand" marriage: A case study in the Kabanjahe District Court (Note 7). This study was conducted largely under the fact that divorce cases are based on those who perform under the hand marriages (without listed intraditional and religious way). This research is a case study, in which makes the study becomes juridical normative. These results indicate that (1) habits, customs, and legal values within the society, the status and interests of the born children, as well as a certificate of marriage from a local village chief is based on the consideration of judge in authorizing traditionally conducted marriage. (2) Marriage in Religion has complied with Article 2 paragraph (1) of Law No. 1 of 1974 and the registration of marriages is administrative. (3) The determination letter of the validity of the marriage by the judge serves to obtain the Marriage Certificate.

Rokhmadi, "Under the hand" Divorce in the Perspective of Islamic Law and Positive Law in Indonesia: A Comparative Analysis (Case Study in Jantho Religious Courts Jurisdiction), Faculty of Law, USU, 2008. Talak divorce is a legal act in the form of marital breakfrom a husband against his wife. In Article 39 paragraph (1) Law No. 1 of 1974 and Article 65Law No. 7 of 1989 it is stated that "Divorce can only be done in front of the trial court after the relevant court tried and unsuccessful in reconciled the two parties (husband and wife). The results of the research confirms that the imposition of talak has to be conducted in front of the Religious Courts does not discord with the basic principles of Islamic law. Instead, it brings the realization of the purpose of the law, which is the benefit. In the other hand,"under the hand" talak will be more open to the form of the non-compliance of rule of talak law. On that basis, talak is obligatory in Religious Court; while the under the hand talak (if it is not restrictied), at least can be categorized as makruh (can be done under several conditions).

The three studies of "under the hand" divorce in general are trying to find the similarities between fiqh and positive law, both considered to be not problematic. Yet the facts on the ground show that there are "lawlessness" of the perpetrators of "under the hand" divorce when they are about to conduct second marriage.

\subsection{Hypothesis and Correspondences of Research Design}

This study puts the "under the hand divorce" into two legal approaches, namely the Islamic Law and Positive Law. Islamic law in this study refers to the law of Islam as understood by the law user-not in the discourse of contemporary fiqh. Legal subjects who continue to believe the validity of divorce out of the court have to face formal legal problems when they want to post-divorce marriage. Thus, they conduct some administrative violations, which in this study it can be concluded that the implementation of positive law generates mudlarat (sin) and contrary to the principle of legal utilities. Therefore, the framework of the study is described in the following charts: 


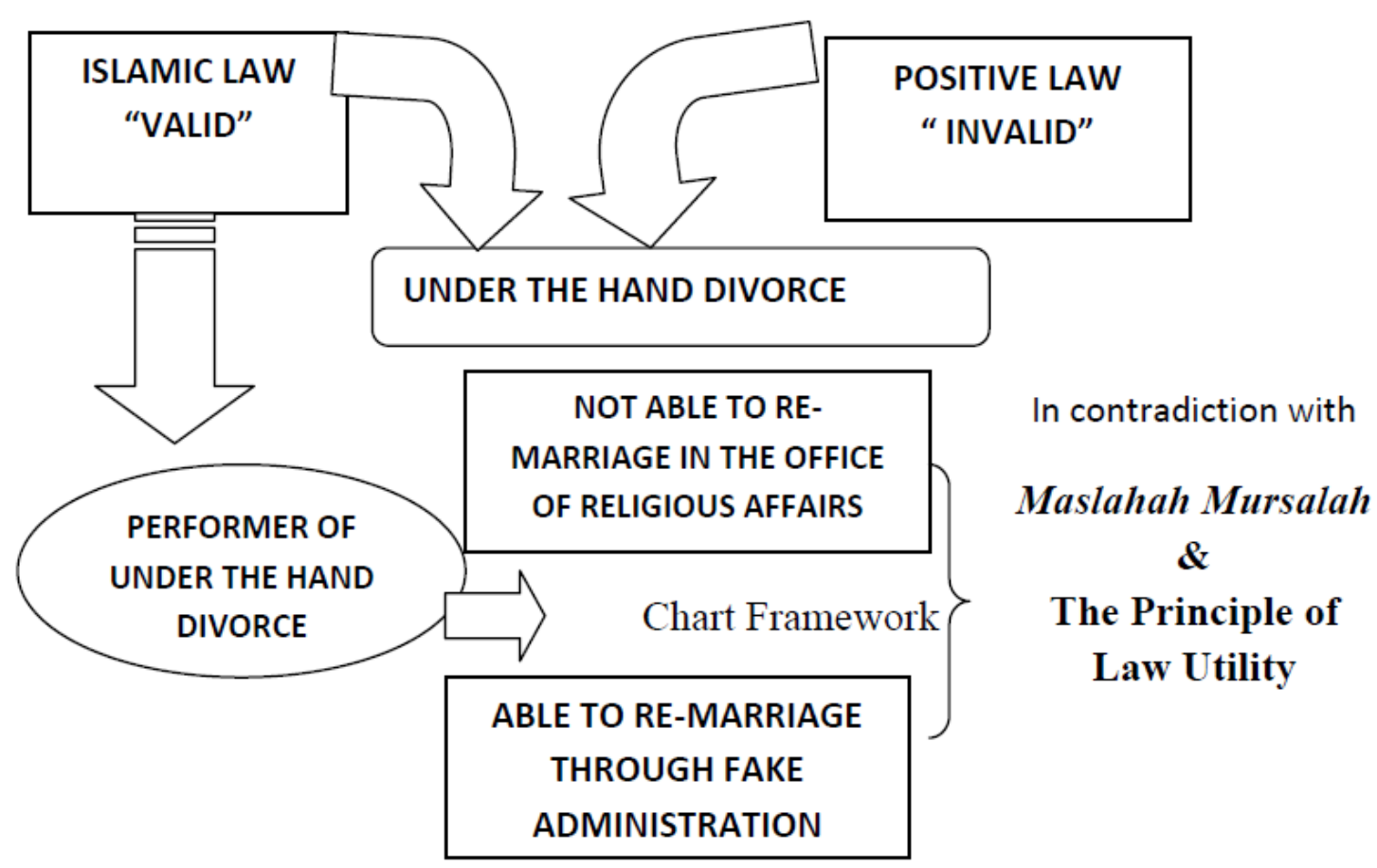

\section{Methods}

\subsection{Subsections Identification}

Research method used in the study is descriptive analysis, which describes the existing laws and regulations thoroughly and systematically. Then, the study solves the problem that arises. The specification of the study used is a literature study and field research.

The data were analyzed qualitatively normative, in which the analysis used without using numbers and statistics and mathematical formulas means to be presented in narrative form. The results of the analysis will be presented descriptively in order to illustrate clearly the position of the "under the hand divorce" in terms of Islamic Law and in accordance to the existing legal law provisions in Indonesia.

\subsection{Participant (Subject) Characteristics}

The practice of divorce is happening in the community, for various reasons, not all done before the religious court. There are still many people who believe that the practice of divorce is carried out outside the trial religion under Islamic law (fiqh) is sufficient and valid. Divorce outside the court is called "divorce under the hand".

No matter if the divorce is done in front of the religious court, because the divorce could be recognized legitimated by Islamic law (fiqh) and Positive Law. But this divorce becomes a problem because it is done outside the court religion of "divorce under the hand", because it is not recognized under the law legitimated positive.

\subsection{Sampling Procedures}

People to be a resource in this study was seven cleric or religious leaders who live in the village Carenang, Carenang District of Serang Regency of Banten Province. The seven people initials: KH. Sm, KH. W, KH. U, S Ustadz Ustadz B, Ustadz Z, and Ustadz M. 


\section{Macrothink}

\section{Result}

\subsection{Recruitment}

\subsubsection{Normative Juridical Analysis of Under the Hand Divorce in Carenang District}

The normative juridical analysis sees the law in its form as rules that determine "what is allowed" and "what is not allowed". The analysis of this study has prescriptive nature, to determine the right and the wrong. This study tends to represent the law in books. Its world is das sollen, what it should be. This normative law study is emphasized on the norms which are currently applicable at that time or the norms stated in the legislation. The method used for the study is juridical-normative method. The study of this normative law research is basically reviewing the law within the literature.

Normative legal study can be used to analyze this "under the hand divorce", especially when the analysis is performed to the positive law. As stated by Hans Kelsen, the normative approach looks at the positive law as the only law. The divorce process considered as valid only if it is enacted before a court. Normative approach attempts to find the truth through deductive way into The Criterion of Coherence Truth. Deductive means "Law assesses inductive reality" (Note 8).

Therefore, the normative assessment of the divorce law can be seen through the following matters, namely the inventory of positive law, the principle of legal research, discovery of the concrete law, the systematic of law, the synchronization and harmonization of law, comparative law, and law history. Last, this study is intended to compare Islamic law, KHI law, and the positive law.

District residents Carenang totaled 38369 people, consisting of Men 18858 and Women 19 511 souls souls who live in the eight (8) existing village.

Table 1. District resident population carenang by village

\begin{tabular}{lllll}
\hline \multirow{2}{*}{ No. } & \multirow{2}{*}{ VILLAGE } & \multicolumn{2}{c}{ TOTAL POPULATION } & \multirow{2}{*}{ AMOUNT } \\
\cline { 3 - 4 } & & MAN & WOMEN & \\
\hline 1. & Carenang & 1.560 & 1.632 & 3.192 \\
2. & Pamanuk & 1.919 & 2.021 & 3.940 \\
3. & Mekarsari & 2.316 & 2.305 & 4.621 \\
4. & Panenjoan & 2.100 & 2.165 & 4.265 \\
5. & Mandaya & 2.329 & 2.413 & 4.742 \\
6. & Teras & 3.098 & 3.255 & 6.353 \\
7. & Walikukun & 2.306 & 2.337 & 4.643 \\
8. & Ragas Masigit & 3.230 & 3.383 & 6.613 \\
\multicolumn{2}{l}{ AMOUNT } & 18.858 & 19.511 & 38.369 \\
\hline
\end{tabular}

Data Source: Data Population District of 2014. 


\section{Macrothink}

Table 2. Head of families in district carenang Year 2014

\begin{tabular}{llll}
\hline No & VILLAGE & HEAD OF FAMILIES & Information \\
\hline & Carenang District & \\
1 & Carenang & 893 \\
2 & Pamanuk & 1.077 \\
3 & Mekarsari & 1.429 \\
4 & Panenjoan & 1.154 \\
5 & Mandaya & 1.297 \\
6 & Teras & 1.811 \\
7 & Walikukun & 1.365 \\
8 & Ragas Masigit & 1.868 \\
& Total & $\mathbf{1 0 . 8 9 4}$ \\
\hline
\end{tabular}

District residents Carenang composition according to the religion one hundred percent $(100 \%)$ are Muslims. Religious education obtained Carenang society through study groups that held almost anywhere. According to the Head of Public Welfare Carenang District of recita is held in the District of Carenang there was held at the ward level village in mosque committees, mosque or the mosque. There is also a district level study conducted once a month in rotation at mosques village in the Sub District of Carenang (Note 9).

To express condition Carenang sociological communities will be presented based on the comparison and analysis of data from Serang District. Subdistrict Carenang based on data obtained from Serang District is a district that is quite poor, had $31 \%$ of poor families, such as in Table 3.

Table 3. Sub-district in the percentage of poor households

\begin{tabular}{lllll}
\hline \multirow{2}{*}{ NO } & \multirow{2}{*}{ Sub-District } & \multicolumn{2}{l}{ Amount Head of Families } & HF Poor \\
\cline { 3 - 5 } & & HF & 4.276 & $59,17 \%$ \\
\hline 1 & Binuang & 7.227 & 3.894 & 42,27 \\
2 & Tanara & 9.212 & 4.306 & 40,37 \\
3 & Tirtayasa & 10.667 & 5.950 & 40,25 \\
4 & Cinangka & 14.781 & 4.846 & 35,68 \\
5 & Pontang & 13.580 & 3.567 & 31,57 \\
\hline
\end{tabular}

Source: BPS Regency Serang, 2010. 
Other data show that the District Carenang is a district that has a poverty rate that is high enough. Of the 10 (ten) villages under Carenang districts, there are five (5) villages are categorized as poor. This figure is equal to the poverty rate Serang District so do generalize what happens in Serang District sociologically as also occurred in the District Carenang.

\subsubsection{Juridical Analysis Hands Down Divorce in Islamic Law}

Divorce in this thesis is limited as the "pronounce of the word talak or divorce or from a husband to his wife". There are two main issues in the divorce law, namely (1) sighat talak, and (2) pledge oftalak, consciously or unconsciously. For that reason, the issues will be discussed one by one.

a. Sighat talak.

A divorce is sighat talak, "divorce statement". For that reason, the Islamic Fiqh provides elaboration regarding sighat that is able to break marriage bond. By pronouncing the word talaq or words with similar meaning means declaring a divorce. This is relevant with the meaning of the word talak which means release or pull out (Note 10) or literally means freeing an animal. It is used in shari'ah to show a legitimate way to terminate a marriage. According to Muhammad Ismail al-Kahlani, Talak is "untie a bond, which is derived from the word ithlaq, which meansto release, pull out" (Note 11).

Meanwhile, according to Wahbah Zuhaily, Talak is "untie or release" (Note 12). On the other hand, Sayyid Sabiq explained that talak can be understood as follows: "Talak in the terms of syarah means to break the bonds of marriage or dissolution of the marriage relationship" (Note 13). It means that the bondof marriage is going to break and the marital relationship will be end in the household if the husband states a divorce statement to his wife.

\section{b. Pledge of Talak}

The pledge of talak has to be conducted consciously with clear intention and strong consideration. Al-Qardawi asserts that lots of fiqh theologians expand divorce even in the state of drunk, angry, or even forced. Whereas hadits state that talak in an unstable emotional condition is not considered as valid and Ibnu Abbas said: "in all conscience divorce comes through a real intention". However, all matters that is proposed by nash and the objective of shari'ah in forming a family and taking care of it means limiting the occurrence of talak. Talak will not happen unless due to the presence of certain words, in certain time, and certain intention as intended by Al-Bukhari and salaf theologians, and is strengthened by Ibnu Taymiyah and Ibnu Al-Qayyim (Note 14).

The main factor of divorce is "the statement of divorce which derived from a real intention." When the statement is pronounced, divorce happens. This is relevant with the principle of al-amru bimaqashidiha that "act happens as the intentions", when the "intended intention" is relevant with "the act/words", then the act is considered as legally valid.

On the basis of the two reviews above, it is argued that Islamic law or fiqh determines the legitimacy of divorce as "a statement of talak in a language (clear, kinayah, speech or letter) that is based on a husband's conscious choice". Thus, once a husband says or writes directly a pledge of talak, a divorce occurs despite the time and place related to the event.

\subsubsection{Juridical Analysis of the Under the Hand Divorceon Positive Law}

The term divorce, according to Law No. 11974 as a positive law regulation on divorce, is: 
a) A law action that can be performed by a husband or wife to break up the marriage bond;

b) Law occurrence that is happened to disconnect a husband and wife relationship, the death of the related husband or wife, which is a definite and direct provision set by God the Almighty;

c) A law decision declared by a court resulted in the breakup of marriage between a husband and wife.

Thus, the term divorce legally means breaking a marriage that resulted on disconnect a relationship as a husband and wife. As defined in the Dictionary of Indonesian above is stop on having relationship as a husband and wife. Subekti provides an understanding of divorce as: "Removal of marriage status through the judge's decision or the demands of one of the parties in the marriage".

According to the positive law in Indonesia, "under the hand divorce" and its consequences do not get the recognition and protection of the law, and therefore it is considered as illegal because it does not conform to the rules of law.

\subsubsection{Comparative Analysis between Positive Law and Islamic Law}

The juridical-normative elaboration of "under the hand divorce" above shows some similarities and differences. Positive law and Islamic law are alike in deciding the "pledge of divorce" from her husband as the determinant of a divorce. The difference lies in the location where the pledge is uttered. In one side, the Islamic law stipulates that a divorce occurs whenever and wherever it is spoken, as long as the pledge is stated based on full awareness. While in the other side, positive law stipulates that divorce must be pledged before the court, a pledge of divorce outside the court will be considered as invalid.

Table 4. The comparison of law status of "under the hand divorce"

\begin{tabular}{lll}
\hline & FIQH & KHI \& Positive Law \\
\hline $\begin{array}{l}\text { Divorce } \\
\text { Definition }\end{array}$ & $\begin{array}{l}\text { Divorce may occur when the pledge } \\
\text { of talak is uttered by the husband } \\
\text { conscious or unconsciously. }\end{array}$ & $\begin{array}{l}\text { Divorce may happen when the pledge } \\
\text { of talak is pronounced by the husband } \\
\text { before the trial court. }\end{array}$ \\
Process & $\begin{array}{l}\text { In any places and at any time, Divorce is considered as valid only if it } \\
\text { without or with witnesses, as long is occurred before the trial court } \\
\text { as there is a utterance of talak or an } \\
\text { issue of divorce letter. }\end{array}$ & $\begin{array}{l}\text { through several analysis process of } \\
\text { reasons, evidences, mediation, and } \\
\text { decisions. }\end{array}$ \\
\hline
\end{tabular}

The differences of law status as seen above are managed to be tranquillized, due to the function of law as the community judicature.

\subsubsection{Juridical Sociological Analysis of the Practice Divorce in Hands Down}

In a life that changes very fast each day, it is strongly seen that the law (positive) cannot function effectively for managing the change and development. Inevitably, the various branches of the social sciences, especially sociology, which recently began to investigate the 
cause of social changes, is being called to solve various problems of social changes that are very relevant to law issues (Note 15). The social sciences that are begun to be viewed within the framework of sociological jurisprudence teaching are started to be used to renew and update the law norms. Studies of sociology of law with its Nomologic-inductive social methods are now being developed and utilized to analyze and provide answers about the problems of the effectiveness of the operation of the whole institutional structure of law.

Laws that are sociologically conceptualized can be used as a scientific research (non-doctrinal) object. Law is no longer used as a tiller in preparing a coherent mere (on the basis of deductive logic) normative system, with premises derived from the matters (either primary or secondary), or from normative sources (formal or material).

A clear feature of methods to be used in a non-doctrinal is by using the role of induction logic in order to find the general principles (empirical uniformities) and theories (either the miniature or the middle range, or the grand), through syllogism. In this induction syllogism, premises (except the conclusions), are always in the form of verified observations. Here lies the difference between the current research study model with the doctrinal model (normative) that is conducted by the philosopher-moralist or theorists-positives in order to find the general principles of positive law. These doctrinal studies are always deductively contradictory from the norms which its truth is formally valued and do not originate from the observation in which the material truth is always questioned and verified. Inductive syllogism is used to acquire descriptive and explanative conclusions of the existing relationship (causal or correlative) between the various variables of socio-law. This is the law of sociological thought (Note 16).

\section{Discussion}

\subsection{Sociological Fact of "Under the Hand" Divorce}

Sociology views religion as a social fact that has certain "power" to encourage individuals in performing a particular action. As a social phenomenon, a social fact is different with individual symptoms. Social fact has three main characteristics: First, social facts are external to the individual. Second, social facts force individuals. An individual is forced, guided, persuaded, encouraged or influenced by various social facts in the public realm. Third, the social fact is common or widely spread in a society. Social facts are collective thus the impact on the individuals is also a result of this collectivity.

Sociologically, there are three things that can be elaborated about the behavior of "under the hand" divorce in Carenang District, namely:

1) "Under the hand" divorce behavior is a social fact. The society of Carenang district is a religious society, in which the majority receives religious instruction since childhood in boarding schools and mosques. Ulama or religious scholars become a source of values and they establish norms of truth and value patterns. The norms and value patterns are called as institution. From this social institution derives a good and bad view of "under the hand" divorce. At the time the religious scholars declared valid to the "under the hand" divorce, then the individual in society would feel "not guilty" when they perform "under the hand" divorce. 
2) Source of law for Carenang's society are the clerics who become their teachers. Rural communities such as Carenang are bounded to itsclerics. Visibly, the scholars are referring to the scriptural sources, but in certain cases - such as how to respond to a special case- they answer based on the teacher's teachings or guidance, or those people considered as teachers. Therefore, although the Compilation of Islamic Law has been applied, sociology of rural community indicates the referral system of value at the nearest scholars, such as teachers. KHI socialization could only have been done-especially when it has not been identified yet as with Carenang society-KHI is still not considered as a reference; only the statement of the teachers considered as the source.

3) In rural communities with low economical status, divorce simply means "the completion of a marriage" and is not associated with the rights related to property. Their demands for the guarantee of post-divorce rights are unthinkable. A thought that often arises when the marriage bond is untenable is a faster divorce, a better.

\section{2 The Sociological Fact of "Under the Hand" Divorce Impact}

Court divorce as a legitimate way is associated with the fulfillment of the citizens' rights after the divorce. When the divorce was legally done, these rights are protected and facilitated by the State; otherwise the citizens who conduct the "under the hand" divorce will not get the rights after divorce. The impact of divorce through the legislation procedure is as follows:

\section{a. Divorce validity}

Marriages conducted according to legislation that is in accordance with the mandated Law No. 1 in 1974 and is valid according to the law. Then, after undergoing domestic life as husband and wife, there appears a problem of households which is resulting in a divorce. However, the divorce is not carried out according to the existing rules, but carried out in accordance with the traditions of Islamic law and the common law tradition. Such conditions will cause major problems later in the future.

The big problem mentioned above can be considered in some acts such as if the husband is remarried with another woman, where the marriage was carried out without following the existing rules and regulations or "under the hand" marriage with his second wife, and the second marriage resulting in a child, then the child will have difficulty in getting law recognition that states the child is a legitimate child of the "under the hand" marriage. It is caused by the status of the second marriage that has no legal force or official documents from the State ("under the hand" marriage). Thus, a new marriage certificate cannot be issued because there is not strong evidence in law which states that the husband has divorced his first wife and he also does not have any divorce certificate.

\section{b. Marital status}

If a husband wants to get married again with another woman, or vice versa, if the wife wants to marry another man, while in terms of divorce the process is not legally complete, or have not been completed by the rules of divorce procedure in an appropriate existing legislation, or yet to undergo a formal divorce procedure. Then, they are not allowed to have another marriage legally, because they are still bounded by the previous marriage.

If a person wants to implement a divorce, then it must be in accordance with the procedures of the existing law as stated in Article 39 paragraph (1) which states that: Divorce can only be 
done in front of the Court after the relevant court tried and unsuccessful in reconciling the two sides; and paragraph (2): To conduct divorce there must be sufficient grounds which state that the couple will not be able to live in harmony anymore as husband and wife.

A divorce is considered as valid legally, if it has a divorce certificate and has undergone the procedure of divorce relevant with what has been set. Legally, both sides will be restricted to perform a second marriage with a different partner. Based on Law No. 1 of 1974 article 15, it is stated that: Whoever by marriage still tied to one of the two sides and on the basis of the persistence of the marriage, can prevent the an occurrence of new marriage, without diminishing the provisions of Article 3 paragraph (2) and Article 4. Article 16 paragraph (1) states that the appointed official is obliged to prevent the continuation of the marriage if the provisions of Article 7 paragraph (1), Article 8, Article 9, Article 10 and Article 12 are not fulfilled. Paragraph (2) on the appointed official as referred to in paragraph (1) of this article further stipulated in the law regulations.

c. Living

If there is a divorce between a husband and wife, then the main target is the children born as a result of a legal marriage occurred between the husband and wife. As Article 41 explains that: The results of marriage breakdown through a divorce are: (a) Neither the mother or father is still obliged to maintain and educate their children, solely based on the interests of the children, if there is a dispute regarding the decision of the sides which will nurture the child. (b) Father is the one who is responsible for all costs of maintenance and education necessary for the child. If the father cannot meet these obligations, the court may determine that the mother collaborates in the responsibility. (c) The court may oblige the former husband to provide cost for living and/or determining any obligation for the former wife.

In fact, if there is a divorce between a husband and wife, most husbands would neglect its obligation to provide a living for their children as an absolute obligation. Thus, the one who becomes the main victim is the children from the marriage. Meanwhile, the law has been set explicitly, in addition, Islamic Law requires the same thing as what has been defined by Act No. 1 of 1974.

In line with the regulations above, it is clear that the status of children born outside of marriage is not recognized by the law. Then, the consequences are that children, born from sirih marriage, have only a civil relationship with her mother and her mother's family. Therefore, the wives did not have legal rights or legislation of demanding a living for the child's needs to be fulfilled by the husband, and the husband would argue that he did not want to be responsible for all the child's needs, because the child was born out of the marital status which is not appropriate with the rules of the existing legislation, namely Law No. 1 of 1974.

\section{d. Shared Wealth Status}

Shared wealth is a wealth that is acquired during the marriage outside the gift or inheritance. In other words, it is a wealth which is acquired from their efforts, together or separately during the marriage times (Note 17).

In terms of fiqh mu 'amalah, the shared wealth can be categorized as syirkah or affiliation between a husband and wife. Conventionally, the economic burden of the family is the husband's livelihood, while the wife as homemaker acts as manager who adjusts their 
household economic management. For a broader definition and adaption to the demands of the social development, the wife can also do a job that can bring wealth. If we refer to the first term, which is included in syirkah al-Abdan, the one who get the living is the husband, while the wife will support him in the management. While the second term, in which each of them brings in capital and manage it together, referred to as 'inan shirkah (Note 18).

\section{e. Palimony and Inheritance Status}

Principally, the issue of inheritance has been set out clearly in Islamic Law Compilation (KHI) about the part of each couple as stated in Article 96 (1) If the divorce because of death occurs, then half of the wealth becomes the right of the left spouse, (2) the share of wealth for a husband or wife in which the wife or husband has a debt should be suspended until the certainty of death is pronounced legally on the basis of the decision of the Religious Court. Then, Article 97 which states about the widow or a divorced in which each of them has right of the shared wealth as long as there is no other stipulations in the marriage covenant.

However, the main problem is that, when a house hold problem occurs and eventually leads to a divorce and the divorce procedures are not in line with what is stipulated in Law No. 1 In 1975, for example, when one conducts a divorce procedure based on Islamic law and the local customary law. In this position, if a husband or wife suddenly dies, while traditionally there has been a divorce law, yet based on the positive law or Act No. 11974 there has been no divorce act because there is no process proposed according to the rules of positive law.

The above situation will result in bad effects for families and children; especially with the fact that local community is more concerned with the local law tradition. Referring to the Islamic law tradition, the shared wealth will be divided in two after the divorce. Automatically, the former wife does not get her former husband's share that die after a divorce in local law tradition.

However, referring to the Law No. 1 of 1974 there is no divorce yet in legal. This is because the former parties have previously disregarded the divorce procedures stated in the rules of the existing legislation. If there has been a divorce between a husband and wife, both in legal traditions as well as the Act No. 1 of 1974, it is clear that familial relationship between the family and the husband and wife must be in a disharmony. While the application of inheritance law could be implemented by both parties who have been divorced with some differences in choosing the law that will be used.

From the description above, on many sides it appears that the "under the hand" divorce is able to develop the neglect of the fulfillment of the post-divorce rights. Women can become victims because they do not earn a living, iddah money, unclear palimony, and the like. Due to the inexistence of divorce certificate, the former husband may vanish after delivering his divorce.

4.3 Islamic Law Analysis of the Implementation of Article 39 of Law No. 1 of 1974 about Marriage and Article 34 of Government Regulation No. 9 of 1975

The readiness of law actors in Islamic law is associated with emergency conditions. Fiqh rules stipulate that the al-masyaqqah tajlib at-Taysir which then produces some derivatives rules associated with the allowance of postponement of the occurred law for the benefit.

First rule, adl-dharurah tubih al-mahzurat (emergency condition can justify things that are 
forbidden). Emergency linguistically means an urgent or extremely need of emergency. The emergency in this case is if a person does not perform that particular thing, then he will be destroyed or nearly destroyed. For example, the need of foods for survival at a time when he was very hungry. Sheikh Abdullah bin Abdurrahman Al Bassam Rahimahullah defines the word emergency (Note 19) as "matters that causethe allowance of performing something forbidden" (Note 20). Meanwhile, mahzhurat are "things that are prohibited or forbidden by Islamic law". Mahzhurat encompasses everything forbidden derived from someone, either in the form of speech such as gibah, provocations, and the like; or in the form of emotional practice such as jealousy, envy, and the like; or also in the form of physical act such as stealing, having intercourse before marriage, drinking wine, and etc (Note 21).

Second Rule, idza dhaqa al-amar Ittasa'a (if an order was a nuisance, then extends [easy]). The meaning of this rule is that if a mukallaf distress by something that make him faces difficulty in performing something, then he gets a breadth and ease. This rule is relevant to its head rule. This rule was first brought up by Imam Shafi'i with his words that became the formulation of the rules of fiqh itself (Note 22). The example of this fiqh is that the forgiveness given for a few filth and blood. It may prevent thieves from their evil deeds which may even lead to kill (if it is hard to resist) (Note 23).

Based on both of these rules, the scholars in Carenang feel that it is acceptablefor some one to avoid performing a law, as long as there is an emergency. These emergencies can take the form of two things, (a) the law has not been socialized well, and (b) economic emergency and the unavailability of legal institutions that make it easier.

Knowledge in Islamic law becomes the basis of the law implementation for mukallaf. The person is called mukallaf, means those who have responsibility for taklifi law enforcement. The basisof taklif to mukallaf is their intelligence and ability to understand it. Saif al-Amidi, as quoted by Muhammad Abu Zahrah, asserted that the scholars have agreed on the terms of becoming amukallaf, that is the person must be intelligent and able to understand takfili (Note 24).

Islamic law divides the level of maslahah into three parts: emergency, somewhat urgent, and just a complement. Al-maslahah al-Daruriyah, is a maslahah that concerns on the essence of things in life, such as maintaining religion, nourish the soul, intellect, lineage and wealth. Al-maslahah al-hajjiyah, or the interests of essential under the level of al-maslahah daruriyyah, but necessary in human life in order to avoid difficulties and the narrowness in life, which will not result in damage to life when it is not obtained, but it leads to the narrowness and hardship in life. While Al-maslahah al-Tahsiniyah, (complementary interests) which will not lead to the narrowness of someone's life when it is not obtained, because the need is not necessary, just as a complement or garnish in his life.

\section{Conclusion}

Based on the findings in the previous chapter, it can be concluded that: First, "under the hand" divorce according to fiqh or Islamic law is considered as valid. In fiqh, the pledge of divorce before the courts is not necessary; while according to Article 39 of Law No. 1 of 1974 on Marriage and Article 34 of Government Regulation No. 9 of 1975, "under the hand" divorce is considered invalid in the eye of the law, because the divorce pledge is not 
pronounced in front of the court; Second, the review of Islamic law on the implementation of Article 39 of Law No. 1 of 1974 on Marriage and Article 34 of Government Regulation No. 9 of 1975 in Carenang District as measured by its level of "mafsadat" and "maslahat" (al-Maslahah al-Daruriyah, Al -Maslahah al-hajjiyah, Al-Maslahah al-Tahsiniyah). Sociological situation of Carenang society does notallow the execution of the divorce laws in court. Divorce for couples whose relationship are not able to be maintained is a part of al-Maslahah al-daruriyyat, where the matters are urged to be conducted; and Third, the implementation of "under the hand" divorce by people in Carenang district is categorized asal-Maslahah al-daruriyyat. Meanwhile, the implementation of divorce in front of the court (legal divorce) is categorized as al-maslahah al-hajjiyat, maslahah which supports the implementation of al-maslahah al-daruriyat.

\section{Acknowledgments}

This research is expected to contribute in the development of law science in general and particularly in Islamic law, and it is expected to be helpful in solving marital problems, especially for the problems of "under the hand" divorce. Besides, the results of this study are expected to be used as an input for the development of science in the field of Islamic law, especially Islamic civil law which concerns on "under the hand" divorce.

With the completion of this paper, the authors would like to thank all resources, Head of the Religious Affairs Office of Carenang District, as well as the head of the Islamic Religious Affairs of Serang District. In particular, the authors would like express his grateful also to the couples in Carenang who are willing to share their marriage stories which are used as theme of the current study.

\section{Reference}

Abu, Z. (1971). Usul al-Fiqh, (Mesir: Dar al-Fikr al-Araby.

Ahmad bin Syaikh Muhammad..., Syarh al-Qawaid..., p.164

Ahmad, R. (2001). Hukum Islam di Indonesia, Jakarta: PT Grafindo Persada.

Al-Bassam, Abdullah bin Abdurrahman. 1416 H. Taudhih al-Ahkam fi Bulugh al-Maram. Dar al-Qiblah li ats-Tsaqafah al-Islamiyah: Jeddah - KSA.

As-Sadlan, Shalih bin Ghanim. 1418 H. Al-Qawaid al-Fiqhiyyah al-Kubra wa Ma Tafarra'a 'Anha, (Dar Balnasiyah: Riyadh - KSA.

Dworkin, R. (2006). Justice in Robes, (Cambridge, Massachusetts, London: The Belknap Press of Harvard University Press, 1 st edition.

Eka, W. (20110). “Kedudukan Perkawinan dan Perceraian di Bawah Tangan ditinjau dari Hukum Islam dan Peraturan Perundang-undangan yang berlaku di Indonesia, Tesis Program Studi Magister Kenotariatan, Pascasarjana Universitas Diponegoro.

Fitria, H. (2007). Perceraian dalam perkawinan di bawah tangan: Studi kasus di Pengadilan Negeri Kabanjahe. Tesis S2 Ilmu Hukum Magister Kenotariatan UGM.

Hans, K. (1995). Teori Hukum Murni. Dasar-Dasar Ilmu Hukum Normatif-sebagai ilmu Hukum Empirik-Deskritif Bandung: Rimdi Press.

Jimly, A. (2008). Peran Advokat dalam Penegakan Hukum, Orasi Hukum pada acara "Pelantikan DPP IPHI Masa Bakti 2007-2012". 
Mahruddin Andry. (Pegawai PA. Sidikalang). "Persinggungan Fikih dengan Pasal 9 Undang-undang Nomor 1 tahun 1974 tentang Perkawinan dan pasal 34 Peraturan Pemerintah nomor 9 tahun 1975 dalam masalah Talak di bawah tangan".

Makinudin, Pandangan Hukum Islam terhadap Pelaksanaan Ikrar Talak di Indonesia Pasca UU No. 1 Tahun 1974, Disertasi, IAIN Sunan Ampel, Surabaya.

Maria, F. I. S. (2007). Ilmu Perundang-undangan 2. Jakarta: Penerbit Kanisius.

Moh, I. (197). Subul al-Salam.Bandung: Pustaka Dahlan.

Mugi, L. (2012). Susanti Analisis Hukum Islam tentang Perceraian di Bawah Tangan (Studi Kasus di Daerah Transmigrasi Desa Mukti Manunggal, Kec. Menthobi Raya, Kab. Lamandau, Kalimantan Tengah, Thesis Progtam passca Sarjana, IAIN Walisongo.

Rony, H. S. (1988). Metode Penelitian Hukum dan Jurimetri, Jakarta: Ghalia Indonesia.

Sajuti, T. (1986). Hukum Kekeluargaan Indonesia, cet. V. Jakarta: UI Press.

Sayyid, S. (1998). Fiqih Sunnah, Alih bahasa oleh Moh. Thalib. Bandung: al-Ma'arif.

Slamet, A. (1999). Fiqih Munakahat II. Bandung: Pustaka Setia.

Soetandyo, W. (2002). Hukum: Paradigma. Metode dan Pilihan Masalahnya, Jakarta: ELSAM.

Suparman, U. (2002). Hukum Islam. Jakarta: Gaya Media Pratama.

Suparman, U. (2011). Pokok-pokok Filsafat Hukum. Serang: Gaya Suhud Sentrautama.

Wahbah al-Zuhaily. (1989). Fiqhu al-Islami wa Adillatuhu Damsyik, Dar al-Fikr.

\section{Notes}

Note 1. Makalah Mahruddin Andry (Pegawai PA. Sidikalang), "Persinggungan Fikih dengan Pasal 9 Undang-undang Nomor 1 tahun 1974 tentang Perkawinan dan pasal 34 Peraturan Pemerintah nomor 9 tahun 1975 dalam Masalah Talak di Bawah Tangan"

Note 2. Suparman Usman, Hukum Islam,(Jakarta:Gaya Media Pratama,2002), h. 246.

Note 3. Abdurrahman,op.cit., h. 74.

Note 4. Ibid,h. 93.

Note 5. Mugi Lestari, Susanti Analisis Hukum Islam tentang Perceraian di Bawah Tangan (Studi Kasus di Daerah Transmigrasi Desa Mukti Manunggal, Kec. Menthobi Raya, Kab. Lamandau, Kalimantan Tengah, Thesis Progtam passca Sarjana, IAIN Walisongo, 2012

Note 6. Fitria Handayani, Perceraian dalam Perkawinan di Bawah Tangan: Studi kasus di Pengadilan Negeri Kabanjahe. Tesis S2 Ilmu Hukum Magister Kenotariatan UGM [Yogyakarta]: 2007id, h. 98.

Note 7. Rony Hanitijo Soemitro, Metode Penelitian Hukum dan Jurimetri, (Jakarta: Ghalia Indonesia, 1988), h. 9

Note 8. Pendekatan kaidah ini mencari tujuan atau maksud dari suatu peraturan perundang-undangan. Amirudin dan Zainal Asyikin, dikutip dari Makinudin, Pandangan Hukum Islam terhadap Pelaksanaan Ikrar Talak di Indonesia Pasca UU No. 1 Tahun 1974, Disertasi, IAIN Sunan Ampel, Surabaya, h. 10.

Note 9. Moh. Ismail al-Kahlani, Subul al-Salam (Bandung: Pustaka Dahlan, 1987), jilid 3, h. 
16813.

Note 10. Wahbah al-Zuhaily, Fiqhu al-Islami wa Adillatuhu (Damsyik, Dar al-Fikr, 1989), juz. VII, h. 356

Note 11. Sayyid Sabiq, Fiqih Sunnah, Alih bahasa oleh Moh. Thalib. (Bandung: al-Ma'arif, 1998), jilid 8, h. 9

Note 12. Ibid., 350.

Note 13. Soetandyo Wignjosoebroto, Hukum: Paradigma. Metode dan Pilihan Masalahnya, (Jakarta: ELSAM, 2002), h. 160

Note 14. Sajuti Thalib, Hukum Kekeluargaan Indonesia, cet. V (Jakarta: UI Press, 1986), h. 89. Lihat juga Ahmad Rofiq, Hukum Perdata Islam di Indonesia, h. 161

Note 15. Ahmad Rofiq. Hukum Islam di Indonesia, (Jakarta: PT Grafindo Persada, 2001), h. 161

Note 16. Ketentuan dan batasa darurat yakni: 1) keadaan darurat benar-benar terjadi, (2) Tidak ada media/jalan mubah lain untuk mencegah kemudaratan tersebut, (3) Darurat menyangkut kebinasaan/kerusakan jiwa dan tubuh, (4) orang yang mengalami keadaan darurat itu tidak boleh melanggar prinsip-prinsip dan akidah Islam, dan melanggar hak-hak orang lain, (4) mahzurat yang dibolehkan itu dalam ukuran sedikit, (5) diketahui wali al-amr ketika darurat umum. Lihat Dr. Shalih Ibn Ghanim as-Sadlan, al-Qawaid al-Fiqhiyyah al-Kubra, (Riyadh: Dar al-Balansiyyah, 1417 H) h. 250

Note 17. Al-Bassam, Abdullah bin Abdurrahman. 1416 H. Taudhih al-Ahkam fi Bulugh al-Maram. Dar al-Qiblah li ats-Tsaqafah al-Islamiyah: Jeddah - KSA. Cetakan ke-1. Jilid ke-1. H. 80

Note 18. Lihat As-Sadlan, Shalih bin Ghanim. 1418 H. Al-Qawaid al-Fiqhiyyah al-Kubra wa Ma Tafarra'a 'Anha, (Dar Balnasiyah: Riyadh - KSA. Cetakan ke-1.) H. 256

Note 19. Izzat Ubaid ad-Di'as, al-Qawaid al-Fiqhiyah..., h. 42. Lihat juga Dr. Shalih Ibn Ghanim as-Sadlan, al-Qawaid al-Fiqhiyyah al-Kubra, (Riyadh: Dar al-Balansiyyah, 1417 H), h. 266

Note 20. Ahmad bin Syaikh Muhammad..., Syarh al-Qawaid..., h.164

Note 21. Abu Zahrah, Usul al-Fiqh, (Mesir: Dar al-Fikr al-Araby, 1971), h. 337

Note 22. Jimly Asshidiqqie, Peran Advokat dalam Penegakan Hukum, Orasi Hukum pada acara “Pelantikan DPP IPHI Masa Bakti 2007-2012”. (Bandung, 19 Januari 2008), h. 2-3.

Note 23. Maria Farida Indrati S., Ilmu Perundang-undangan 2 Jakarta: Penerbit Kanisius, , 2007), h. 152.

Note 24. Dworkin, Ronald, Justice in Robes, (Cambridge, Massachusetts, London: The Belknap Press of Harvard University Press, 1st edition, 2006), h. 223. 


\section{Copyright Disclaimer}

Copyright for this article is retained by the author(s), with first publication rights granted to the journal.

This is an open-access article distributed under the terms and conditions of the Creative Commons Attribution license (http://creativecommons.org/licenses/by/3.0/). 